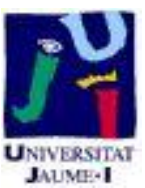

Título artículo / Títol article: Reciprocal regulation between AtNRT2.1 and AtAMT1.1 expression and the kinetics of NH4+ and NO3- influxes

Autores / Autors

Gemma Camañes, Elena Bellmunt, Javier García-Andrade, Pilar García-Agustín, Miguel Cerezo

Revista:

Journal of Plant Physiology (2012), vol. 169, issue 3

Versión / Versió:

Versión post-print del autor

Cita bibliográfica / Cita bibliogràfica (ISO 690):
CAMAÑES, Gemma, et al. Reciprocal regulation between AtNRT2.1 and AtAMT1.1 expression and the kinetics of NH4+ and NO3- influxes. Journal of Plant Physiology, 2012, vol. 169 , no. 3 , p. $268-274$. 


\title{
Reciprocal regulation between AtNRT2.1 and AtAMT1.1 expression and the kinetics of $\mathrm{NH}_{4}{ }^{+}$and $\mathrm{NO}_{3}{ }^{-}$influxes
}

\author{
Gemma Camañes ${ }^{\mathrm{a}, 1}$, Elena Bellmunt ${ }^{\mathrm{a}, 1}$, Javier García-Andrade ${ }^{\mathrm{b}}$, Pilar García-Agustín ${ }^{\mathrm{a}}$, Miguel Cerezo ${ }^{\mathrm{a}, *}$

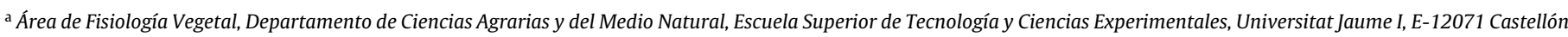 \\ de la Plana, Spain

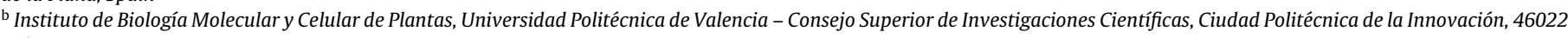 \\ Valencia, Spain
}

\section{A R T I C L E I N F O}

\section{Article history:}

Received 5 May 2011

Received in revised form 17 October 2011

Accepted 18 October 2011

\section{Keywords: \\ AMT1 \\ NRT2 \\ $\mathrm{NH}_{4}{ }^{+}$influx \\ $\mathrm{NO}_{3}-$ influx}

\begin{abstract}
A B S T R A C T
Our results show that AtNRT2.1 expression has a positive effect on the $\mathrm{NH}_{4}{ }^{+}$ion influx, mediated by the HATS, as also occurs with AtAMT1.1 expression on the $\mathrm{NO}_{3}{ }^{-}$ion influx. AtNRT2.1 expression plays a key role in the regulation of AtAMT1.1 expression and in the $\mathrm{NH}_{4}{ }^{+}$ion influx, differentiating the nitrogen source, and particularly, the lack of it. Nitrogen starvation produces a compensatory effect by AtAMT1.1 when there is an absence of the AtNRT2.1 gene. Our results also show that, in the atnrt2 mutant lacking both AtNRT2.1 and AtNRT2.2, gene functions present different kinetic parameters on the $\mathrm{NH}_{4}{ }^{+}$ion influx mediated by the HATS, according to the source and availability of nitrogen. Finally, the absence of $A M T 1.1$ also produces changes in the kinetic parameters of the $\mathrm{NO}_{3}{ }^{-}$influx, showing different $V_{\max }$ values depending on the source of nitrogen available.
\end{abstract}

(c) 2011 Elsevier GmbH. All rights reserved.

\section{Introduction}

Nitrogen $(\mathrm{N})$ can be found in the soil as a complex blend of organic and inorganic compounds, with $\mathrm{NO}_{3}{ }^{-}$and $\mathrm{NH}_{4}{ }^{+}$ions as the main sources of mineral $\mathrm{N}$ available for plant nutrition. Because these $\mathrm{N}$ forms can show high variability in the soil, both in space and in time, plants have had to develop a set of different uptake systems to adapt themselves to the external conditions and their nutritional requirements. There are multigenic families, both for the $\mathrm{NO}_{3}{ }^{-}$transporters and for the $\mathrm{NH}_{4}{ }^{+}$transporters, indicating that different genes play different roles in $\mathrm{N}$ nutrition and allow the plant to adapt to different environmental conditions by means of regulating these genes. Members of the NRT2 gene family encode high-affinity $\mathrm{NO}_{3}{ }^{-}$transporters (Forde, 2000), whereas the AMT1 multigenic family genes encode high-affinity $\mathrm{NH}_{4}{ }^{+}$transporters in different plant species (Howitt and Udvardi, 2000).

Among the components of the NRT2 family, up to 7 in Arabidopsis thaliana (Orsel et al., 2002), it seems that NRT2.1 is a major component of the $\mathrm{NO}_{3}{ }^{-} \mathrm{HATS}$, as illustrated by the fact that several mutants disrupted the NRT2.1 gene (Little et al., 2005; Li et al., 2007) or both NRT2.1 - NRT2.2 genes (Cerezo et al., 2001; Filleur et al., 2001) lost up to $72 \%$ of the high affinity $\mathrm{NO}_{3}{ }^{-}$uptake activity. NRT2.1 expression is regulated by $\mathrm{N}$ sources and their concentra-

\footnotetext{
* Corresponding author.

E-mail address: cerezo@camn.uji.es (M. Cerezo).

1 These authors contributed equally to this work.
}

tions (Filleur and Daniel-Vedele, 1999; Gansel et al., 2001; Girin et al., 2007; Okamoto et al., 2003; Zhuo et al., 1999) and there is increasing evidence that NRT2 transporters are also regulated at the posttranscriptional level in various species (Fraisier et al., 2000; Wirth et al., 2007). Castaings et al. (2011) suggest that $\mathrm{NO}_{3}{ }^{-}$ is rapidly and specifically sensed by plant cells and that a $\mathrm{NO}_{3}{ }^{-}$ signaling pathway adjusts the expression of a large set of genes to adapt cell and organ metabolism and growth to N availability.

With regard to the AMT1 family, the AtAMT1.1, AtAMT1.2 and AtAMT1.3 genes contribute to the influx mediated by the HATS. Influx measurements in a T-DNA insertion line showed that AMT1.1 is responsible for about $30 \%$ of the ammonium acquisition in Arabidopsis roots (Kaiser et al., 2002). It appears that the AtAMT1.1 gene may be responding to differences in $\mathrm{N}$ concentration and source. AMT1.1 expression is regulated similarly to NRT2.1 by $\mathrm{N}$ sources and their concentrations (Gazzarrini et al., 1999; Rawat et al., 1999; Camañes et al., 2009), and at the posttranslational level, AMT1.1 can be inactivated by C-terminal phosphorylation that interacts with neighboring subunits in a trimer (Loqué et al., 2007).

We can draw from all of these studies that the regulation of $\mathrm{N}$ uptake is a complex and highly regulated process that depends on both endogenous and exogenous factors of the plant. Recently, we have advanced in molecular knowledge of $\mathrm{N}$ sensing in plants, such as the dual function of the nitrate transport CHL1 (Muños et al., 2004; Ho et al., 2009; Wang et al., 2009), the roles of different transcription factors (Rubin et al., 2009; Wang et al., 2009) or of the protein kinases (Ho et al., 2009; Hu et al., 2009). Proof 
of the complexity of the process can be obtained when observing interactions among different genes. In A. thaliana, the reciprocal regulating interaction that might exist in the expression of genes from the same family, and even from different families, has been shown (Cerezo et al., 2001; Muños et al., 2004). Krouk et al. (2006) showed that NRT1.1 expression takes part in NRT2.1 expression. Kaiser et al. (2002) showed the existence of a compensatory effect by the AtAMT1.2 and AtAMT1.3 genes when there is an absence of the AtAMT1.1 gene. This compensatory effect also occurs with the AtNRT2.2 gene. This gene makes only a small contribution to the $\mathrm{NO}_{3}{ }^{-}$HATS, except that when AtNRT2.1 is lost, its contribution increases and results in a partial compensation (Li et al., 2007). NAR2.1/NRT3.1 has been described as a trans-membrane protein that is involved in the NRT2.1 transporter post-translational regulation, but it has no transporter activity in itself (Okamoto et al., 2006; Orsel et al., 2006). Surprisingly, atnar2.1 null mutants display stronger HATS activity reduction than the double mutant atnrt2.1atnrt2.2 (Orsel et al., 2006). There are some indications that NRT2.1 could also act either as a $\mathrm{NO}_{3}{ }^{-}$sensor or signal transducer to coordinate the development of the root system and coordinate it with nutritional cues (Little et al., 2005). Because NRT2.1 presents a dual nutrient transport/signaling function, it could be considered a putative $\mathrm{NO}_{3}{ }^{-}$transceptor (Gojon et al., 2011).

Due to the importance of the NRT2.1 and AMT1.1 genes in N nutrition in low external $\mathrm{N}$ concentration conditions, and due to the fact that both genes respond by de-repressing with a lack of $\mathrm{N}$ and induction because of low $\mathrm{N}$ concentrations, the aim of this work was to examine the effect of AtNRT2.1 expression on the regulation of AtAMT1.1 expression and on the kinetic parameters of the influx, and vice versa.

\section{Materials and methods}

\section{Plant material and growth conditions}

The Arabidopsis thaliana genotypes used in this study were the wild type Wassilewskija (Ws) the Ws mutant atnrt2 (atnrt2.1-2.2) (Filleur et al., 2001), the EMS lin1 line (Little et al., 2005) and the amt1-1:T-DNA mutant (Kaiser et al., 2002) and their corresponding wild type in the Col-0 and Col-3 gl1 backgrounds, respectively. All plant genotypes were grown hydroponically as described in Lejay et al. (1999). The seeds were germinated directly on top of modified eppendorf tubes filled with pre-wetted sand. The tubes were then positioned on floating rafts transferred on tap water in a growth chamber under the following environmental conditions: light/dark cycle $8 \mathrm{~h} / 16 \mathrm{~h}$, light intensity $200 \mu \mathrm{mol} \mathrm{s}{ }^{-1} \mathrm{~m}^{-2}$, temperature $25^{\circ} \mathrm{C} / 20^{\circ} \mathrm{C}$, hygrometry $80 \%$. After 1 week, the tap water was replaced by complete nutrient solution. Then, plants were grown until the age of 6 weeks on a $1 \mathrm{mM} \mathrm{NH}_{4} \mathrm{NO}_{3}$ nutrient solution (control plants), which prevented any growth difference between the four genotypes (data not shown) (Lejay et al., 1999; Cerezo et al., 2001). Before the experiments, nitrogen was supplied as $1 \mathrm{mM}$ $\mathrm{NO}_{3}{ }^{-}$for $24 \mathrm{~h}\left(\mathrm{~N}_{-} \mathrm{NO}_{3}{ }^{-}\right.$induced plants $), 0.1 \mathrm{mM} \mathrm{NH}_{4}{ }^{+} 24 \mathrm{~h}\left(\mathrm{~N}-\mathrm{NH}_{4}{ }^{+}\right.$ induced plants) or $48 \mathrm{~h}$ on nitrogen-free solution (de-repressed plants). The other nutrients were added as described in Lejay et al. (1999). Nutrient solutions were aerated vigorously, renewed weekly and the day before the experiments, $\mathrm{pH}$ was adjusted at 6.0 .

All experiments were repeated three or five times, and typical results are shown.

Root influxes of ${ }^{15} \mathrm{NO}_{3}{ }^{-}$and ${ }^{15} \mathrm{NH}_{4}^{+}$

An influx of either ${ }^{15} \mathrm{NO}_{3}{ }^{-}$(Col and amt1-1:T-DNA plants) or ${ }^{15} \mathrm{NH}_{4}{ }^{+}$(WS and atnrt2 plants) into the roots was assayed as described by Delhon et al. (1995) and Gazzarrini et al. (1999), respectively. Control plants, $\mathrm{N}-\mathrm{NO}_{3}{ }^{-}$or $\mathrm{N}-\mathrm{NH}_{4}{ }^{+}$induced plants and de-repressed plants of four genotypes were sequentially transferred to $0.1 \mathrm{mM} \mathrm{CaSO}_{4}$ for $1 \mathrm{~min}$ and to complete nutrient solution (pH 6.0) containing either ${ }^{15} \mathrm{NO}_{3}{ }^{-}$or ${ }^{15} \mathrm{NH}_{4}{ }^{+}$(98\% atom excess $\left.{ }^{15} \mathrm{~N}\right)$ for $5 \mathrm{~min}$, at the concentrations indicated in figures. At the end of the ${ }^{15} \mathrm{~N}$ labeling, roots were washed for $1 \mathrm{~min}$ in $0.1 \mathrm{mM} \mathrm{CaSO}_{4}$ and were separated from shoots. The roots were dried at $70^{\circ} \mathrm{C}$ for $48 \mathrm{~h}$, weighed, crushed in a hammer-mill and analyzed for total ${ }^{15} \mathrm{~N}$ content using an integrated system for continuous flow isotope ratio mass spectrometry (Euro-EA elemental analyser, EuroVector S.P.A. and Isoprime mass spectrometer, GV Instruments). Root influx is expressed in $\mu \mathrm{mol}^{15} \mathrm{NO}_{3}{ }^{-}$or ${ }^{15} \mathrm{NH}_{4}^{+}(\mathrm{g} \operatorname{root} \mathrm{DW})^{-1} \mathrm{~h}^{-1}$.

Kinetics of ${ }^{15} \mathrm{NO}_{3}{ }^{-}$and ${ }^{15} \mathrm{NH}_{4}{ }^{+}$influx

The kinetics of ${ }^{15} \mathrm{NO}_{3}{ }^{-}$influx (Col and amt1-1:T-DNA plants) and ${ }^{15} \mathrm{NH}_{4}{ }^{+}$influx (WS and atnrt2 plants) as a function of external ${ }^{15} \mathrm{NO}_{3}{ }^{-}$or ${ }^{15} \mathrm{NH}_{4}{ }^{+}$concentrations $\left(\left[{ }^{15} \mathrm{NO}_{3}{ }^{-}\right]_{0}\right.$ and $\left.\left[{ }^{15} \mathrm{NH}_{4}{ }^{+}\right]_{0}\right)$ were measured with $\left[{ }^{15} \mathrm{NO}_{3}{ }^{-}\right]_{0}$ or $\left[{ }^{15} \mathrm{NH}_{4}{ }^{+}\right]_{0}$ ranging from $0.02 \mathrm{mM}$ to $0.8 \mathrm{mM}$. For the kinetics studies, control plants, $\mathrm{N}_{-} \mathrm{NO}_{3}{ }^{-}$or $\mathrm{N}-\mathrm{NH}_{4}{ }^{+}$induced plants and de-repressed plants of four genotypes were used. A data transformation method based on the Michaelis-Menten formalism was used to obtain $V_{\max }$ and $K_{\mathrm{m}}$ estimates. The experiment was repeated three times.

\section{RNA extraction and Real-time PCR analysis}

Gene expression by quantitative real-time RT-PCR was performed using RNA samples extracted from root tissue using the Total Quick RNA kit (TALENT, Italy) according to the manufacturer's instructions. To avoid contaminating DNA, the samples were treated with DNAse I. A total of $1 \mu \mathrm{g}$ of total RNA was annealed to oligo-dT and reverse transcribed using Omniscript Reverse Transcription kit (QIAGEN) to obtain cDNA. The sequences of the gene-specific oligonucleotides designed and used for real-time PCR are the following: AMT1.1 forward: 5'acactgtggccagttaggcg3' and reverse: 5'ccgtggggatgtctttgaga3', NRT2.1 forward: 5'agtcgcttgcacgttacctg3' and reverse: 5'accetctgacttggcgttctc $3^{\prime}$; $\beta$-Tubuline (TUB) forward: 5'cgattccgttctcgatgttgt3' and reverse: 5'aatgagtgacacacttggaatcctt3' and $E F 1 \alpha$ forward: 5'gtcgattctggaaagtcgacc3' and reverse: 5'aatgtcaatggtgataccacgc3'. Real-time PCR was conducted using the QuantiTect ${ }^{\mathrm{TM}}$ SYBR Green PCR Kit (QIAGEN) and the SmartCycler II instrument (Cepheid). The experiment was repeated three times.

\section{Results and discussion}

Is there reciprocal regulation between AtNRT2.1 and AtAMT1.1 expression and influxes, mediated by the HATS, of $\mathrm{NH}_{4}{ }^{+}$and $\mathrm{NO}_{3}{ }^{-}$, respectively?

The induction of $\mathrm{NH}_{4}{ }^{+}$and $\mathrm{NO}_{3}{ }^{-}$influxes mediated by the HATS and the induction of the AtAMT1.1 and AtNRT2.1 expression, by $\mathrm{NO}_{3}{ }^{-}$and $\mathrm{NH}_{4}{ }^{+}$, together with de-repression due to a lack of N, has been shown previously (Filleur and Daniel-Vedele, 1999; Gazzarrini et al., 1999; Gansel et al., 2001; Okamoto et al., 2003). However, there are no studies examining the $\mathrm{NH}_{4}{ }^{+}$influx and AtAMT1.1 expression in plants which lack AtNRT2.1 function as well as the influence of AtAMT1.1 in $\mathrm{NO}_{3}{ }^{-}$influx and AtNRT2.1 expression, both genes involved in $\mathrm{N}$ uptake.

Our results show that when WS and atnrt2 plants grow in $1 \mathrm{mM}$ of $\mathrm{NH}_{4} \mathrm{NO}_{3}$ there are no significant differences in the $\mathrm{NH}_{4}{ }^{+}$ ion influx mediated by the HATS, and the average value is up to $60.5 \pm 2.0 \mu \mathrm{mol}(\mathrm{g} \mathrm{DW})^{-1} \mathrm{~h}^{-1}$ (Fig. $1 \mathrm{~A}$ ). Under the same conditions, the $\mathrm{NO}_{3}{ }^{-}$ion influx, mediated by the HATS, in Col and 

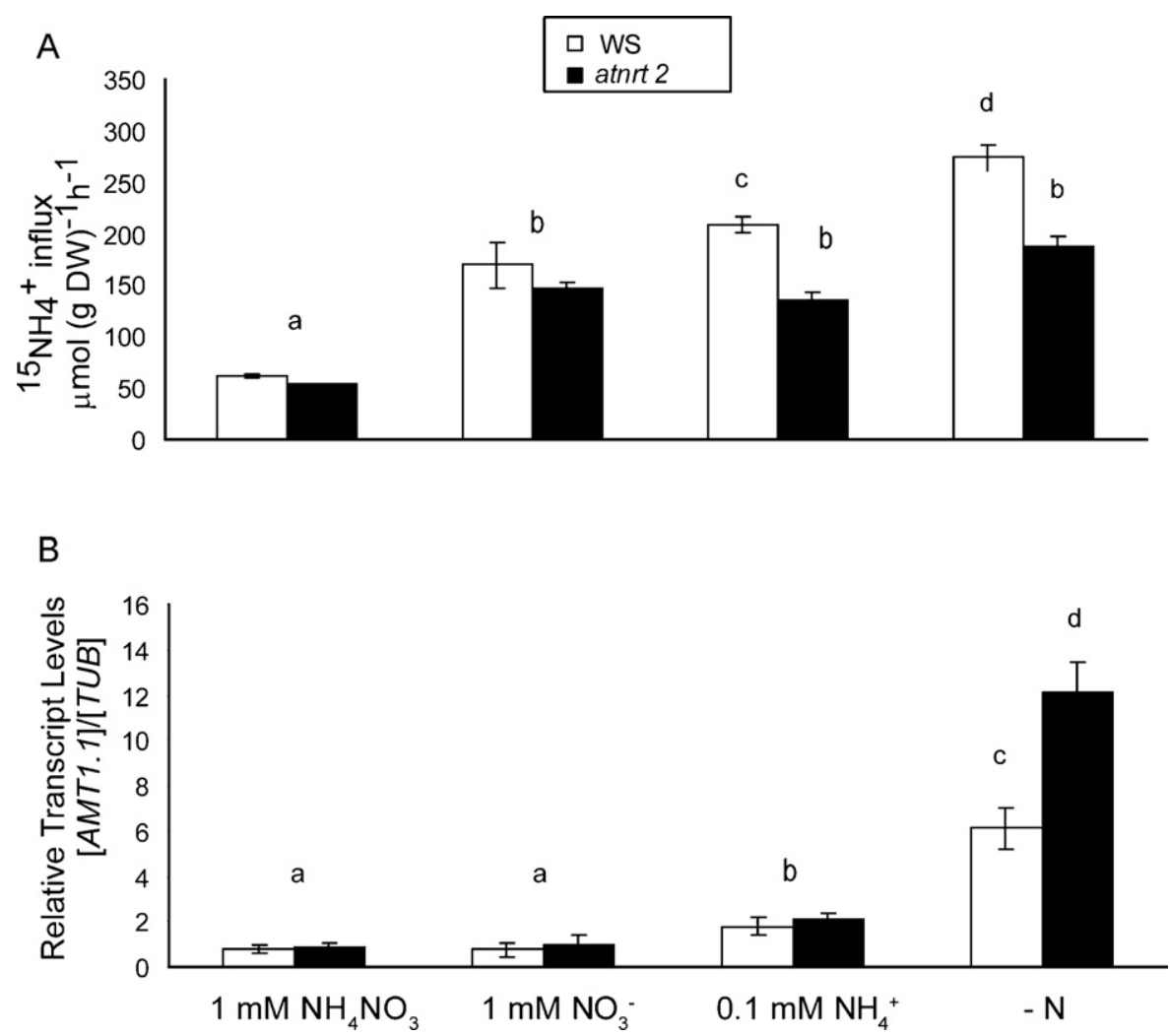

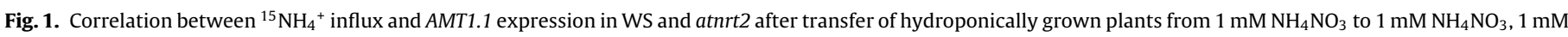

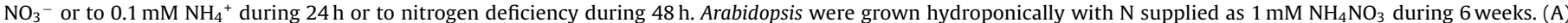

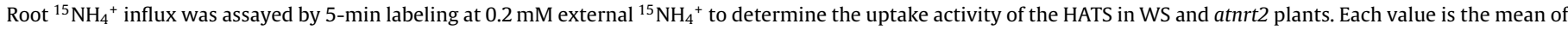

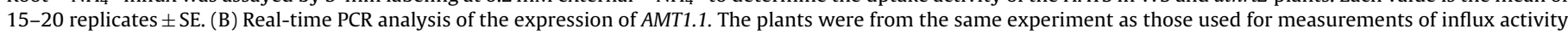

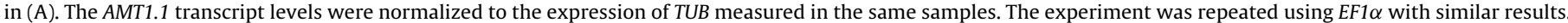

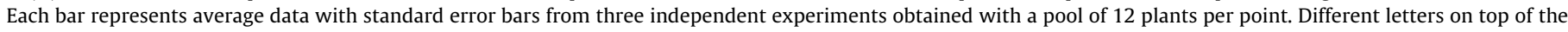
bars indicate statistically significant differences $(P<0.05 ; t$ test $)$.

amt1-1:T-DNA plants does not show significant differences and the average value is $18.3 \pm 1.2 \mu \mathrm{mol}(\mathrm{g} \mathrm{DW})^{-1} \mathrm{~h}^{-1}$ (Fig. 2A). These influx values are similar to the order of magnitude observed by other authors in plants grown under similar conditions (Cerezo et al., 2001; Gansel et al., 2001; Loqué et al., 2006). Similarly, we observed that AtAMT1.1 expression is equal in WS and atnrt2 plants and AtNRT2.1 expression does not show significant differences in Col and amt1-1:T-DNA plants in these conditions. In addition, the level of expression of AtAMT1.1 and AtNRT2.1 are the same among the 4 genotypes (Figs. 1B and 2B). Although the exclusive nutrition with $\mathrm{NH}_{4}{ }^{+}$may result in toxicity for plants (Britto and Kronzucker, 2002), the fact that plants prefer to absorb $\mathrm{NH}_{4}{ }^{+}$rather than $\mathrm{NO}_{3}{ }^{-}$when both forms of $\mathrm{N}$ are present in the environment at a low concentration has been shown in $A$. thaliana and other vegetable species (Gebler et al., 1998; Gazzarrini et al., 1999; Camañes et al., 2009). This can be explained by the lower energy cost for the plant when assimilating $\mathrm{N}^{-\mathrm{NH}_{4}}{ }^{+}$(Bloom et al., 1992). Although AtAMT1.1 and AtNRT2.1 expression are not different, the $\mathrm{NH}_{4}{ }^{+}$ion influx is three times higher than the $\mathrm{NO}_{3}{ }^{-}$ion influx, which could be explained by the larger capacity of HATS for $\mathrm{NH}_{4}{ }^{+}$ion than for $\mathrm{NO}_{3}{ }^{-}$ion (Kronzucker et al., 1995, 1996).

When WS and atnrt2 plants are treated with $1 \mathrm{mM}$ of $\mathrm{NO}_{3}{ }^{-}$ over $24 \mathrm{~h}$, an induction of the $\mathrm{NH}_{4}{ }^{+}$ion influx three times higher is observed compared to control plants ( $1 \mathrm{mM} \mathrm{NH}_{4} \mathrm{NO}_{3}$ ), with no differences between the two genotypes, and the average value is $170.7 \pm 7.6 \mu \mathrm{mol}(\mathrm{g} \mathrm{DW})^{-1} \mathrm{~h}^{-1}$. This induction cannot be explained by an increase in AtAMT1.1 expression, which remains constant and at the same level as in control plants (Fig. 1). Similarly, Col and amt1.1:T-DNA show an induction of the $\mathrm{NO}_{3}{ }^{-}$ion influx of $41 \pm 2.3 \mu \mathrm{mol}(\mathrm{g} \mathrm{DW})^{-1} \mathrm{~h}^{-1}$ and $28 \pm 1.8 \mu \mathrm{mol}(\mathrm{g} \mathrm{DW})^{-1} \mathrm{~h}^{-1}$, respectively. This difference in the $\mathrm{NO}_{3}{ }^{-}$influx value is significant and is not correlated to AtNRT2.1 expression, which remains constant in both genotypes, although it shows an induction with an expression two times higher than in plants grown with $1 \mathrm{mM}$ $\mathrm{NH}_{4} \mathrm{NO}_{3}$ (Fig. 2). Our results seem to indicate that AtNRT2.1 expression does not exert any control on the $\mathrm{NH}_{4}{ }^{+}$ion influx or on AtAMT1.1 expression in the induction mediated by $\mathrm{NO}_{3}{ }^{-}$, whereas AtAMT1.1 expression seems to be involved in the $\mathrm{NO}_{3}{ }^{-}$ion influx induction without affecting the AtNRT2.1 expression.

When plants are treated with $0.1 \mathrm{mM} \mathrm{NH}_{4}{ }^{+}$over $24 \mathrm{~h}$, the $\mathrm{NH}_{4}{ }^{+}$ion influx induction is produced both in WS and atnrt2 plants, although the influx is almost 4-fold [220.0 $\pm 5.7 \mu \mathrm{mol}$ $(\mathrm{g} \mathrm{DW})^{-1} \mathrm{~h}^{-1}$ ] higher in WS and 3-fold [150.3 $\pm 4.8 \mu \mathrm{mol}$ (g $\mathrm{DW})^{-1} \mathrm{~h}^{-1}$ ] higher in atnrt2 compared to plants grown with $1 \mathrm{mM}$ $\mathrm{NH}_{4} \mathrm{NO}_{3}$ (Fig. 1A). An induction of AtAMT1.1 expression is also observed without differences between the two genotypes (Fig. 1B). Similarly, differing induction of $\mathrm{NO}_{3}{ }^{-}$influx is produced in Col $\left[58.6 \pm 8.3 \mu \mathrm{mol}(\mathrm{g} \mathrm{DW})^{-1} \mathrm{~h}^{-1}\right]$ and $\left[42.0 \pm 2.2 \mu \mathrm{mol}(\mathrm{g} \mathrm{DW})^{-1} \mathrm{~h}^{-1}\right]$ in amt1-1:T-DNA plants (Fig. 2A). A very strong induction of AtNRT2.1 expression is also produced and does not show differences between genotypes (Fig. 2B). These results seem to indicate that, in the induction mediated by $\mathrm{NH}_{4}{ }^{+}$, AtNRT2.1 expression exerts some control over the $\mathrm{NH}_{4}{ }^{+}$ion influx and none over AtAMT1.1 expression. Under the same conditions, AtAMT1.1 expression seems to be involved in the induction of the $\mathrm{NO}_{3}{ }^{-}$ion influx without affecting AtNRT2.1 expression.

When plants are under conditions lacking $\mathrm{N}$ for $48 \mathrm{~h}$, significant differences are observed in both the $\mathrm{NH}_{4}{ }^{+}$ion influx and 

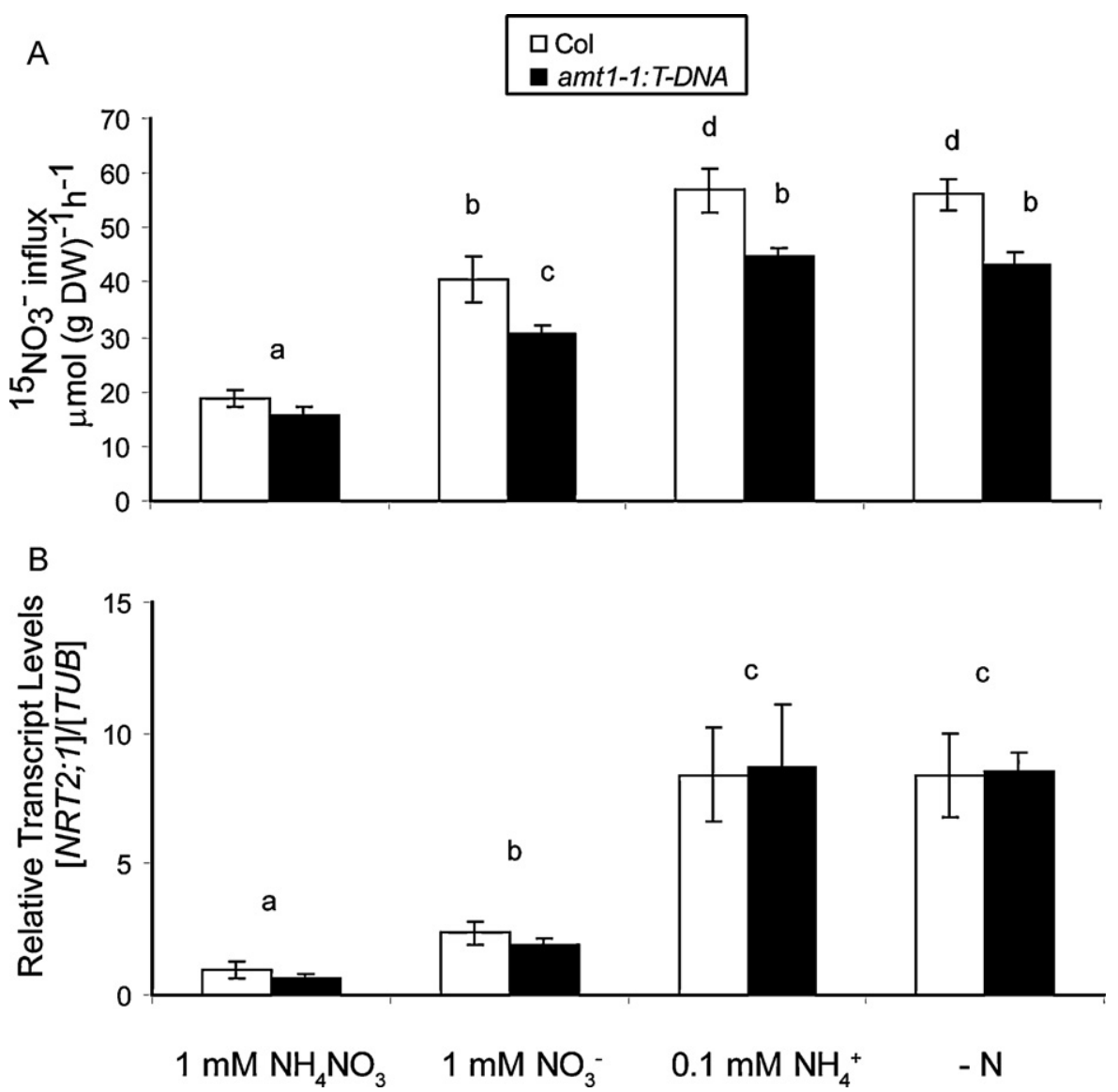

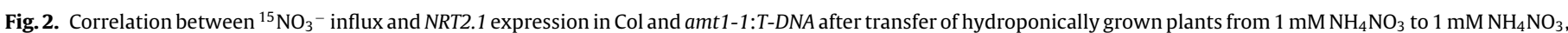

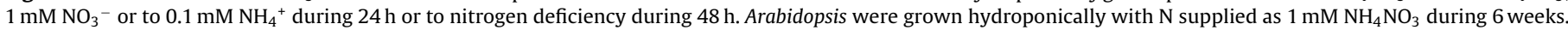

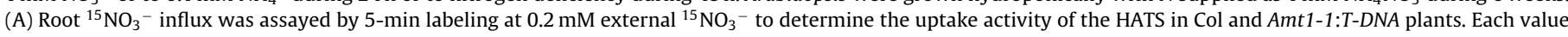

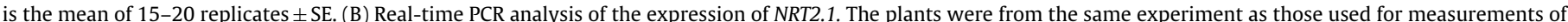

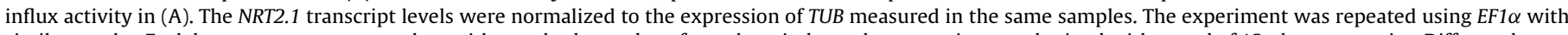

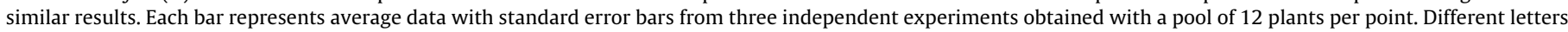
on top of the bars indicate statistically significant differences $(P<0.05 ; t$ test $)$.

AtAMT1.1 expression in WS and atnrt2 plants (Fig. 1). The $\mathrm{NH}_{4}{ }^{+}$ion influx is $275.1 \pm 6.7 \mu \mathrm{mol}(\mathrm{g} \mathrm{DW})^{-1} \mathrm{~h}^{-1}$ in WS and $172.4 \pm 4.4 \mu \mathrm{mol}$ $(\mathrm{g} \mathrm{DW})^{-1} \mathrm{~h}^{-1}$ in atnrt2 plants, and AtAMT1.1 expression shows a great de-repression (approximately 6 -fold more than in plants that have remained with $1 \mathrm{mM} \mathrm{NH}_{4} \mathrm{NO}_{3}$ ) in WS plants, whereas the AtAMT1.1 gene de-repression in atnrt2 plants is 12 -fold (Fig. 1). A differential increase of the $\mathrm{NO}_{3}{ }^{-}$influx around $60.3 \pm 3.3 \mu \mathrm{mol}(\mathrm{g}$ $\mathrm{DW})^{-1} \mathrm{~h}^{-1}$ and $40.2 \pm 3.2 \mu \mathrm{mol}(\mathrm{g} \mathrm{DW})^{-1} \mathrm{~h}^{-1}$ also occurs in the Col and amt1-1:T-DNA plants respectively. This increment is similar to the one produced by the $0.1 \mathrm{mM}$ of $\mathrm{NH}_{4}{ }^{+}$treatment (Fig. 2A). $\mathrm{N}$ starvation de-repressed AtNRT2.1 with no difference between both genotypes, and somehow this effect is also observed in $\mathrm{NH}_{4}{ }^{+}$treatment (Fig. 2B). The results seem to indicate that, in de-repression mediated by the lack of N, AtNRT2.1 expression exerts some control over the $\mathrm{NH}_{4}{ }^{+}$ion influx and AtAMT1.1 expression, whereas AtAMT1.1 expression seems to be involved in the $\mathrm{NO}_{3}{ }^{-}$ion influx induction without affecting AtNRT2.1 expression.

Li et al. (2007) examined HATS activity in AtNRT2.1 and AtNRT2.2 single and double mutants and showed that AtNRT2.1 is responsible for $72 \%$ of the HATS activity. This result suggests that AtNRT2.2 makes only a small contribution to the system, except when AtNRT2.1 is lost. In that case, its contribution increases and results in a partial compensation. The single mutant AtNRT2.1 (lin1) was also subjected to $\mathrm{N}$ starvation for $48 \mathrm{~h}$ and we observed the same results as for the double mutant atnrt2. In conditions lacking $\mathrm{N}$, Col and lin1 plants show a great AMT1.1 gene de-repression. This de-repression in lin 1 plants was double that in the wild type (Fig. 3). This result could indicate that the AtNRT2.2 gene does not play an important role in controlling AtAMT1.1 expression.

The differences observed in both ecotypes between the transcription levels of the AtAMT1.1 and AtNRT2.1 genes and their

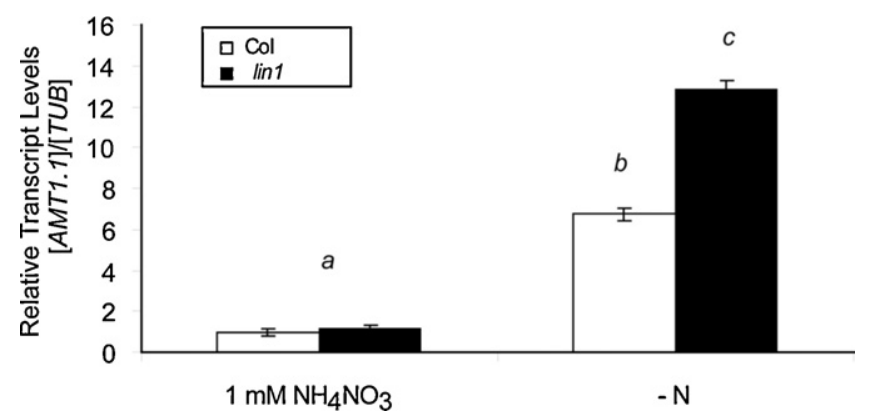

Fig. 3. AMT1.1 expression in Col and lin1 after transfer of hydroponically grown plants from $1 \mathrm{mM} \mathrm{NH}_{4} \mathrm{NO}_{3}$ to $1 \mathrm{mM} \mathrm{NH}_{4} \mathrm{NO}_{3}$ or to nitrogen deficiency during $48 \mathrm{~h}$. Arabidopsis were grown hydroponically with $\mathrm{N}$ supplied as $1 \mathrm{mM} \mathrm{NH} \mathrm{NO}_{3}$ during 6 weeks. Real-time PCR analysis of the expression of AMT1.1. The AMT1.1 transcript levels were normalized to the expression of $T U B$ measured in the same samples. The experiment was repeated using $E F 1 \alpha$ with similar results. Each bar represents average data with standard error bars from three independent experiments obtained with a pool of 12 plants per point. Different letters on top of the bars indicate statistically significant differences $(P<0.05 ; t$ test $)$. 
$1 \mathrm{mM} \mathrm{NH}_{4} \mathrm{NO}_{3}$

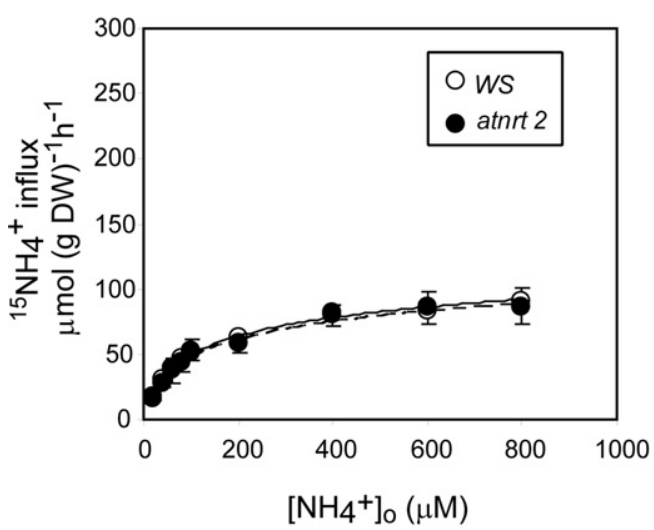

\section{$0,1 \mathrm{mM} \mathrm{NH}_{4}^{+}$}

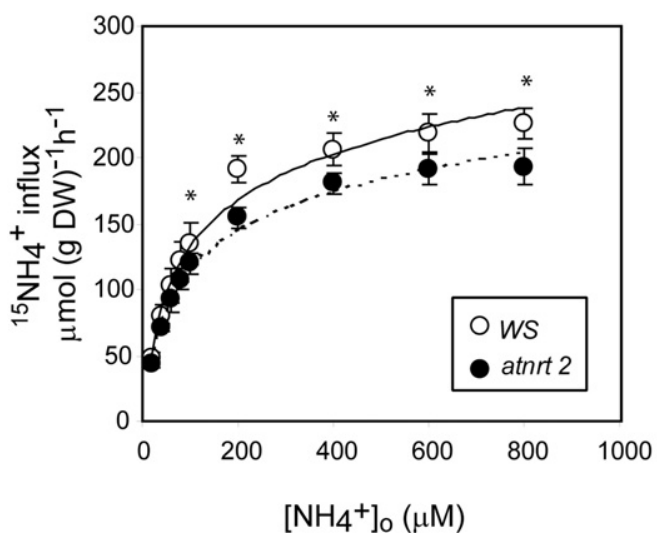

$1 \mathrm{mM} \mathrm{NO}_{3}^{-}$

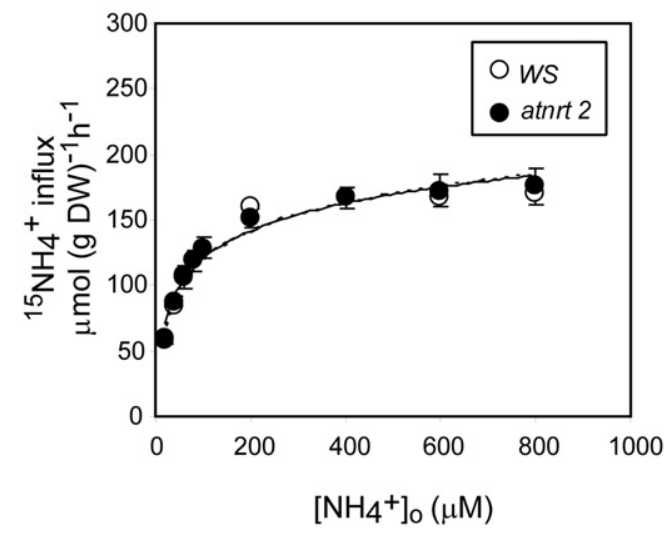

$-\mathbf{N}$

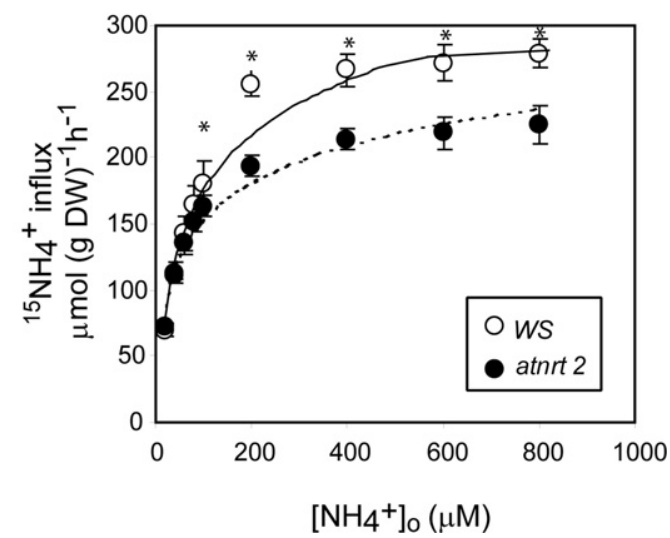

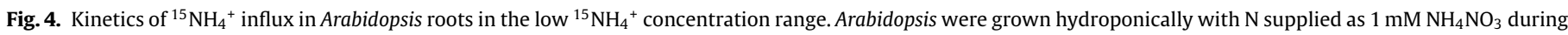

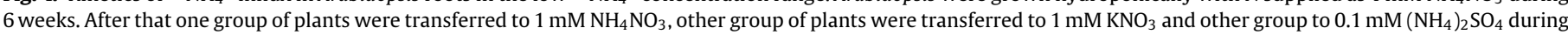

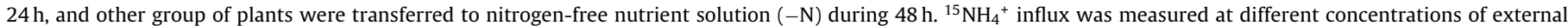
${ }^{15} \mathrm{NH}_{4}{ }^{+}$. Each data is the mean of 30 replicates \pm SE. *Statistically significant differences $(P<0.05 ; t$ test $)$.

respective influxes of $\mathrm{NH}_{4}^{+}$and $\mathrm{NO}_{3}^{-}$(Figs. 1 and 2) led us to study the kinetic parameters in the different treatments. The kinetic parameters of the $\mathrm{NH}_{4}{ }^{+}$ion influx mediated by HATS in WS and atnrt2 plants and, $\mathrm{NO}_{3}{ }^{-}$ion influx mediated also by the HATS in Col and amt1-1:T-DNA plants, were measured. Our results show that plants grow with a continuous contribution from both $\mathrm{N}$ sources ( $1 \mathrm{mM} \mathrm{NH}_{4} \mathrm{NO}_{3}$ ), and do not exhibit significant differences between the kinetic parameters of the WS and atnrt2 plants (Fig. 4 and Table 1) or Col and amt1-1:T-DNA plants (Fig. 5 and Table 1). The kinetic parameters again show the greater capacity of the $\mathrm{NH}_{4}{ }^{+}$ion influx mediated by the HATS when compared to that of $\mathrm{NO}_{3}{ }^{-}$ion. The value obtained for $V_{\max }$ is three times higher, with no significant differences in the $K_{\mathrm{m}}$ (Table 1 ) when plants grow with both sources of $\mathrm{N}$. These values are similar to those obtained by other researchers in analogous culture conditions (Cerezo et al., 2001; Gansel et al., 2001; Loqué et al., 2006). These results indicate that, in mineral nutrition conditions with both sources of $\mathrm{N}$, there is no reciprocal effect of AtNRT2.1 and AtAMT1.1 expression on the $\mathrm{NH}_{4}{ }^{+}$and $\mathrm{NO}_{3}{ }^{-}$influxes, respectively, or over the expression of each gene.

A different response was observed among the two ecotypes in the induction treatment with $1 \mathrm{mM} \mathrm{NO}_{3}{ }^{-}$. We found a 2 -fold induction compared to the control with no significant differences between genotypes (Fig. 4 and Table 1) in the capacity and affinity $\left(V_{\max }\right.$ and $\left.K_{\mathrm{m}}\right)$ of the $\mathrm{NH}^{+}$influx, whereas an induction is also produced but with significant differences between Col and amt1.1:T-DNA plants. In this case, there is a loss of $15 \%$ in the induction capacity in mutant plants, and this effect happens

Table 1

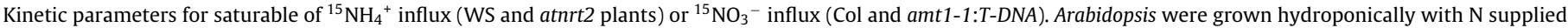

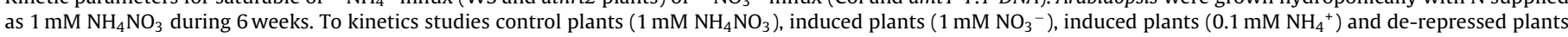
$(-\mathrm{N})$ were used. $K_{\mathrm{m}}$ is measured in $\mu \mathrm{M}$ and $V_{\max }$ in $\left[\mu \mathrm{mol}(\mathrm{g} \mathrm{DW})^{-1} \mathrm{~h}^{-1}\right]$.

\begin{tabular}{|c|c|c|c|c|c|c|c|c|}
\hline & \multicolumn{2}{|c|}{$1 \mathrm{mM} \mathrm{NH}_{4} \mathrm{NO}_{3}$} & \multicolumn{2}{|c|}{$1 \mathrm{mM} \mathrm{NO}_{3}^{-}$} & \multicolumn{2}{|c|}{$0.1 \mathrm{mM} \mathrm{NH}_{4}^{+}$} & \multicolumn{2}{|l|}{$-\mathrm{N}$} \\
\hline & $K_{\mathrm{m}}$ & $V_{\max }$ & $K_{\mathrm{m}}$ & $V_{\max }$ & $K_{\mathrm{m}}$ & $V_{\max }$ & $K_{\mathrm{m}}$ & $V_{\max }$ \\
\hline WS & $95 \pm 6$ & $102 \pm 10$ & $40 \pm 3$ & $178 \pm 12$ & $85 \pm 5$ & $250 \pm 15^{*}$ & $57 \pm 4$ & $302 \pm 15$ \\
\hline atnrt2 & $100 \pm 8$ & $99 \pm 8$ & $44 \pm 2$ & $185 \pm 15$ & $82 \pm 6$ & $217 \pm 12^{*}$ & $52 \pm 6$ & $238 \pm 12$ \\
\hline $\mathrm{Col}$ & $124 \pm 12$ & $32 \pm 2$ & $100 \pm 9$ & $58 \pm 3^{*}$ & $120 \pm 9$ & $76 \pm 5^{*}$ & $30 \pm 2$ & $81 \pm 5^{*}$ \\
\hline amt1.1:T-DNA & $115 \pm 9$ & $28 \pm 2$ & $120 \pm 11$ & $49 \pm 2^{*}$ & $115 \pm 11$ & $62 \pm 5^{*}$ & $28 \pm 2$ & $60 \pm 4^{*}$ \\
\hline
\end{tabular}

* Statistically significant differences between values $(P<0.05$; $t$ test). 
$1 \mathrm{mM} \mathrm{NH}_{4} \mathrm{NO}_{3}$

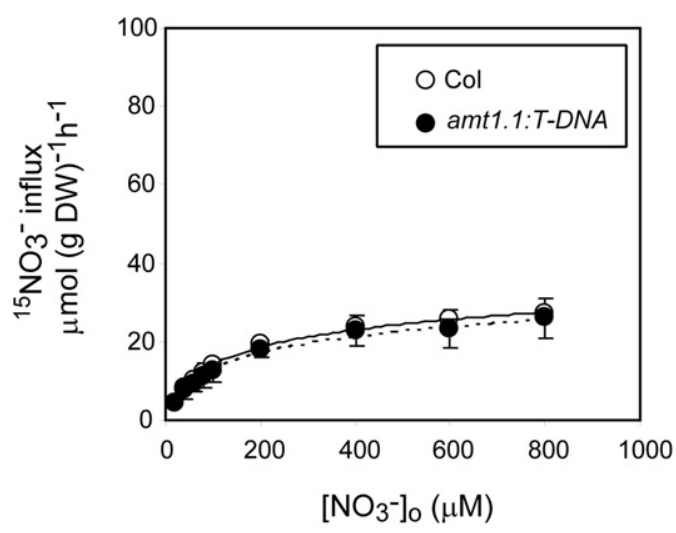

$0,1 \mathrm{mM} \mathrm{NH}_{4}{ }^{+}$

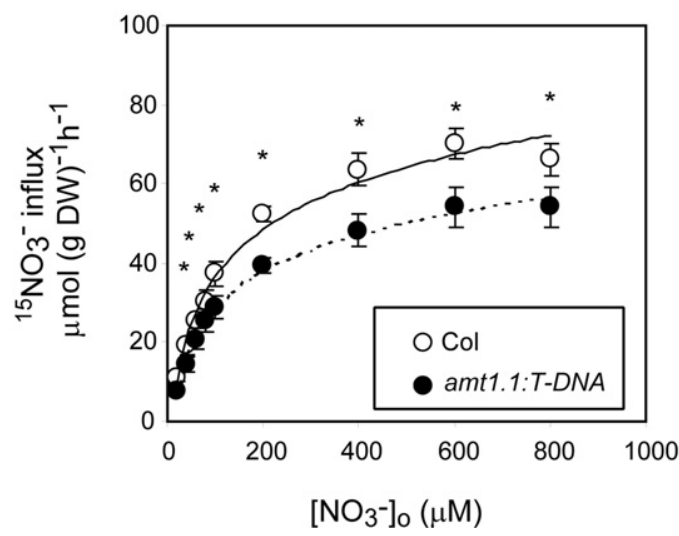

$1 \mathrm{mM} \mathrm{NO}_{3}^{-}$

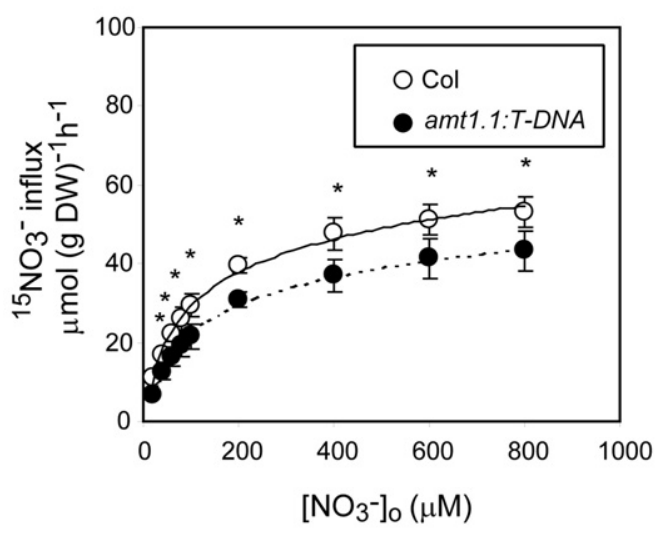

$-\mathrm{N}$

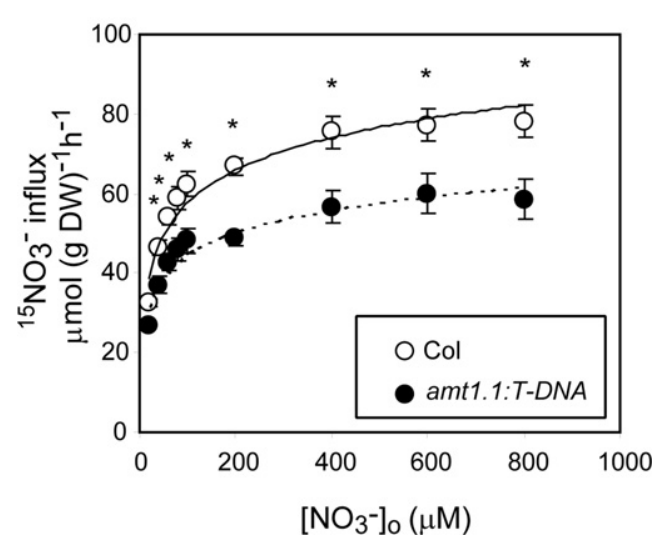

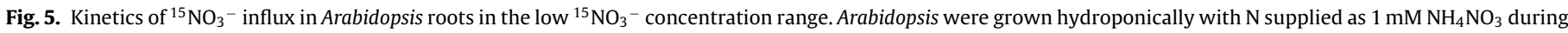

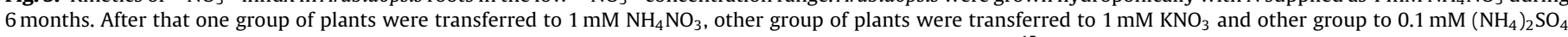

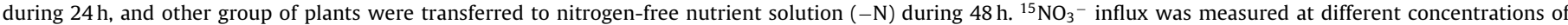
external ${ }^{15} \mathrm{NO}_{3}{ }^{-}$. Each data is the mean of 30 replicates \pm SE. *Statistically significant differences $(P<0.05 ; t$ test $)$.

without modifying their affinity for the substrate (Fig. 5 and Table 1). These results suggest that AtNRT2.1 expression induced by $\mathrm{NO}_{3}{ }^{-}$does not have an influence on AtAMT1.1 expression and $\mathrm{NH}_{4}{ }^{+}$ ion influx, but that AtAMT1.1 is important for the regulation of $\mathrm{NO}_{3}{ }^{-}$ uptake.

When plants are treated with $0.1 \mathrm{mM} \mathrm{NH}_{4}{ }^{+}$, similar results are obtained in both ecotypes if compared with its corresponding mutant. In WS and atnrt2 plants there is a higher influx induction than the produced in the previous treatment. Nevertheless, this difference in the induction can be more easily attributed to the increase of $V_{\max }$ than to the decrease of $K_{\mathrm{m}}$ (the affinity for the substrate is not altered in these plants) (Fig. 4 and Table 1). atnrt2 mutant plants lost $13 \%$ of their response capacity to the induction with $\mathrm{NH}_{4}{ }^{+}$. Col and amt1-1:T-DNA plants also undergo a differential induction with this treatment in which $K_{\mathrm{m}}$ is not altered, while $V_{\text {max }}$ is increased in both cases, although in amt1-1:T-DNA mutant plants there is a smaller increase, such as $18 \%$ (Fig. 5 and Table 1). It appears that AtNRT2.1 expression does not have an effect on the induction of AtAMT1.1 expression, but it somehow regulates the $\mathrm{NH}_{4}{ }^{+}$ion influx, modifying the $V_{\max }$ value. Likewise, AtAMT1.1 expression does not affect the induction of AtNRT2.1, but it affects the $V_{\max }$ value. The most notable results regarding the function of the AtNRT2.1 and AtAMT1.1 expression are those obtained with the treatment lacking $\mathrm{N}$. In that case, there is no difference between the affinity for $\mathrm{NH}_{4}{ }^{+}$ion in WS and atnrt2 plants, which is higher than in plants that have grown with $1 \mathrm{mM} \mathrm{NH}_{4} \mathrm{NO}_{3}$ or in those plants treated with $\mathrm{N}-\mathrm{NH}_{4}{ }^{+}$. Nevertheless, the capacity for the ion influx is diminished by $22 \%$ in atnrt2 plants (Fig. 4 and Table 1 ). Moreover, a strong difference in AtAMT1.1 expression exists between genotypes (Figs. 1 and 3). With regard to Col and amt1-1:T-DNA plants (Fig. 5 and Table 1), similar results to those obtained in the treatment with $\mathrm{N}-\mathrm{NH}_{4}{ }^{+}$are found; these similar results refer to $V_{\text {max }}$ (18\% less in mutant plants), without altering $K_{\mathrm{m}}$ between genotypes. It reaches the lowest values among the 4 treatments. It appears that AtNRT2.1 expression affects the de-repression of the AtAMT1.1 gene by means of some transcriptional mechanism, and it also acts on the regulation of $\mathrm{NH}_{4}{ }^{+}$uptake. On the other hand, AtAMT1.1 expression does not affect AtNRT2.1 expression, but we observed a modification of the $V_{\max }$ value.

For first time, we show the effect of a gene involved in $\mathrm{N}$ transport over another gene of a different family but involved in the $\mathrm{N}$ uptake. Taking these results together, it seems that the functions and importance of both AtNRT2.1 and AtAMT1.1 differ with respect to the regulation of one gene over the others, in different nutritional conditions in which the sources and concentrations of available $\mathrm{N}$ are altered. It is possible that AtNRT2.1 expression may be a sign that could inform the plant of the type of $\mathrm{N}$ source available. Ho et al. (2009) confirmed the signaling function for other $\mathrm{NO}_{3}{ }^{-}$transporters such as NRT1.1. It would also play an important role in regulating the AtAMT1.1 expression at the transcriptional level. Its role as a long distance signal that indicates lack of $\mathrm{N}$ to the whole plant has been reported by Gansel et al. (2001). AtAMT1.1 
expression would never regulate AtNRT2.1 expression at the transcriptional level with different $\mathrm{N}$ sources.

Taking all these results into consideration, AtNRT2.1 expression seems to favor the $\mathrm{NH}_{4}{ }^{+}$uptake, mediated by the HATS differently, depending on the $\mathrm{N}$ source or on the lack of this element. It plays a major role in the AtAMT1.1 gene de-repression in conditions lacking $\mathrm{N}$, showing differences between WS and atnrt2 that could indicate a compensatory effect of AtAMT1.1 expression due to the absence of AtNRT2.1. AtAMT1.1 expression also favors the $\mathrm{NO}_{3}{ }^{-}$ion influx by means of some mechanism independently of the $\mathrm{N}$ source used $\left(\mathrm{N}-\mathrm{NH}_{4}{ }^{+}\right.$or $\left.\mathrm{N}-\mathrm{NO}_{3}{ }^{-}\right)$. Moreover, it seems that it does not affect the regulation of the AtNRT2.1 expression.

To explain the discrepancy observed between the AtAMT1.1 and AtNRT2.1 gene transcription levels and their respective $\mathrm{NH}_{4}{ }^{+}$ and $\mathrm{NO}_{3}{ }^{-}$ion influx, it is possible that, in mutant plants, other AMT1 or NRT2 transporters could be affected, modifying the $\mathrm{NH}_{4}{ }^{+}$ and $\mathrm{NO}_{3}{ }^{-}$HATS activity. Even proteins not belonging to any of these gene families, like NAR2/NRT3-1, could be altered on the atamt1.1-TDNA mutant, triggering a reduction of $\mathrm{NH}_{4}{ }^{+}$uptake, or AtAMT1.1 and AtNRT2.1 transporters could be regulated at the post-transcriptional level under these conditions.

It is not surprising that AtNRT2.1 expression plays a more complex role than the AtAMT1.1. Recently, AtNRT2.1 was suggested as a putative $\mathrm{NO}_{3}{ }^{-}$transceptor because it presents a dual nutrient transport/signaling function (Gojon et al., 2011). Remans et al. (2006) concluded that the NRT2.1 protein is responsible for the coordination of the root development with external availability of $\mathrm{NO}_{3}{ }^{-}$. We believe that AtNRT2.1 expression represents a key point in producing the induction and/or de-repression of the AtAMT1.1 gene, as well as the $\mathrm{NH}_{4}{ }^{+}$ion influx regulation, mediated by the HATS, depending on the $\mathrm{N}$ source.

\section{Acknowledgements}

We thank Dr. Françoise Daniel-Vedele (Unité de la Nutrition Azoté des Plantes, INRA, Versailles, France); Dr. Jocelyn Malamy (University of Chicago, EEUU) and Dr. Nicolaus von Wirén (Molekulare Pflanzenernährung, Universität Hohenheim, Stuttgart, Germany) for providing the atnrt2 mutant, the lin1 mutant and the amt1-1:T-DNA mutant, respectively. This work was supported by the Pla de Promoció de la Investigació de la Universitat Jaume I 2004 and 2010 (P1 1A2004-22 and P1.1B2010-06). We thank the Servicio Central de Instrumentación Científica (SCIC) of the Universitat Jaume I where ${ }^{15} \mathrm{~N}$ analysis was performed.

\section{References}

Bloom AJ, Sukrapanna SS, Warner RL. Root respiration associated with ammonium and nitrate absorption and assimilation by barley. Plant Physiol 1992;99:1294-301.

Britto DT, Kronzucker $\mathrm{HJ} . \mathrm{NH}_{4}{ }^{+}$toxicity in higher plants: a critical review. J Plant Physiol 2002; 159:567-84.

Camañes G, Cerezo M, Primo-Millo E, Gojon A, García-Agustín P. Ammonium transport and CitAMT1 expression are regulated by $\mathrm{N}$ in Citrus plants. Planta 2009;229:331-42.

Castaings L, Marchive C, Meyer C, Krapp A. Nitrogen signalling in Arabidopsis: how to get insights into a complex signalling network. J Exp Bot 2011;62: 1391-7.

Cerezo M, Tillard P, Filleur S, Munos S, Daniel-Vedele F, Gojon A. Major alterations of the regulation of root $\mathrm{NO}_{3}{ }^{-}$uptake are associated with the mutation of $\mathrm{Nrt2.1}$ and Nrt2.2 genes in Arabidopsis. Plant Physiol 2001;127:262-71.

Delhon P, Gojon A. Tillard P, Passama L. Diurnal regulation of $\mathrm{NO}_{3}{ }^{-}$uptake in soybean plants. 1. Changes in $\mathrm{NO}_{3}{ }^{-}$influx, efflux, and $\mathrm{N}$ utilization in the plant during the day-night cycle. J Exp Bot 1995;46:1585-94.

Filleur S, Daniel-Vedele F. Expression analysis of a high-affinity nitrate transporter isolated from Arabidopsis thaliana by differential display. Planta 1999;207:461-9.

Filleur S, Dorbe MF, Cerezo M, Orsel M, Granier F, Gojon A, et al. An Arabidopsis T-DNA mutant affected in Nrt2 genes is impaired in nitrate uptake. FEBS Lett 2001;489:220-4.
Forde BG. Nitrate transporters in plants: structure, function and regulation. Biochim Biophys Acta 2000;1465:219-35.

Fraisier V, Gojon A, Tillard P, Daniel-Vedele F. Constitutive expression of putative high-affinity nitrate transporter in Nicotiana plumbaginifolia: evidence for posttranscriptional regulation by a reduced nitrogen source. Plant J 2000;23:489-96.

Gansel X, Munos S, Tillard P, Gojon A. Differential regulation of the $\mathrm{NO}_{3}{ }^{-}$and $\mathrm{NH}_{4}{ }^{+}$ transporter genes AtNrt2.1 and AtAmt1.1 in Arabidopsis: relation with longdistance and local controls by N status of the plant. Plant J 2001;26:143-55.

Gazzarrini S, Lejay T, Gojon A, Ninnemann O, Frommer WB, von Wirén N. Three functional transporters for constitutive, diurnally regulated, and starvation-induced uptake of ammonium into Arabidopsis roots. Plant Cell 1999;11:937-47.

Gebler A, Schneider S, von Sehgbusch D, Weber P, Hanemann U, Huber C, et al. Field and laboratory experiments on net uptake of nitrate and ammonium by the roots of spruce (Picea abies) and beech (Fagus sylvatica) trees. New Phytol 1998; $138: 275-85$

Girin T, Lejay L, Wirth J, Widiez T, Palenchar PM, Nazoa P, et al. Identification of a $150 \mathrm{bp}$ cis-acting element of the AtNRT2.1 promoter involved in the regulation of gene expression by the $\mathrm{N}$ and $\mathrm{C}$ status of the plant. Plant Cell Environ 2007;30:1366-80.

Gojon A, Krouk G, Perrine-Walker F, Laugier E. Nitrate transceptor(s) in plants. J Exp Bot 2011;62:2299-308.

Ho CH, Lin SH, Hu HC, Tsay YF. CHL1 functions as a nitrate sensor in plants. Cell 2009;138:1184-94.

Howitt SM, Udvardi MK. Structure, function and regulation of ammonium transporters in plants. Biochim Biophys Acta 2000;1465:152-70.

$\mathrm{Hu} \mathrm{H}$, Wang Y, Tsay Y. AtCIPK8, a CBL-interacting protein kinase, regulates the lowaffinity phase of the primary nitrate response. Plant J 2009;57:264-78.

Kaiser BN, Rawat SR, Siddiqi MY, Masle J, Glass ADM. Functional analysis of an Arabidopsis T-DNA "Knockout" of the high-affinity $\mathrm{NH}_{4}{ }^{+}$transporter AtAMT1.1. Plant Physiol 2002;130:1263-75.

Kronzucker HJ, Siddiqi MY, Glass ADM. Kinetics of $\mathrm{NO}_{3}{ }^{-}$influx in spruce. Plant Physiol 1995;109:319-26.

Kronzucker HJ, Siddiqi MY, Glass ADM. Kinetics of $\mathrm{NH}_{4}{ }^{+}$influx in spruce. Plant Physiol 1996;110:773-9.

Krouk G, Tillard P, Gojon A. Regulation of the high-affinity $\mathrm{NO}_{3}{ }^{-}$uptake system by NRT1.1-mediated $\mathrm{NO}_{3}{ }^{-}$demand signalling in Arabidopsis. Plant Physiol 2006;142:1075-86.

Lejay L, Tillard P, Lepetit M, Olive FD, Filleur S, Daniel-Vedele F, et al. Molecular and functional regulation of two $\mathrm{NO}_{3}{ }^{-}$uptake systems by $\mathrm{N}$ - and C-status of Arabidopsis plants. Plant J 1999;18:509-19.

Li W, Wang Y, Okamoto M, Crawford NM, Siddiqi MY, Glass ADM. Dissection of the AtNRT2.1, AtNRT2.2 inducible high-affinity nitrate transporter gene cluster. Plant Physiol 2007;143:425-33.

Little DY, Rao H, Oliva S, Daniel-Vedele F, Krapp A, Malamy JE. The putative highaffinity nitrate transporter NRT2.1 represses lateral root initiation in response to nutritional cues. Proc Natl Acad Sci USA 2005;102:13693-8.

Loqué D, Lalonde S, Looger LL, von Wiren N, Frommer WB. A cytosolic transactivation domain essential for ammonium uptake. Nature 2007;446:195-8.

Loqué D, Yuan L, Kojima S, Gojon A, Wirth J, Gazzarrini S, et al. Additive contribution of AtAMT1.1 and AtAMT1.3 to high-affinity ammonium uptake across the plasma membrane of nitrogen-deficient Arabidopsis roots. Plant J 2006;48:522-34.

Muños S, Cazettes C, Fizames C, Gaymard F, Tillard P, Lepetit M, et al. Transcript profiling in the chl1-5 mutant of Arabidopsis reveals a role of the nitrate transporter NRT1.1 in the regulation of another nitrate transporter, NRT2.1. Plant Cell 2004; $16: 2433-47$

Okamoto M, Kumar A, Li WB, Wang Y, Siddiqi MY, Crawford NM, et al. High-affinity nitrate transport in roots of Arabidopsis depends on expression of the NAR2-like gene AtNrt3.1. Plant Physiol 2006;140:1036-46.

Okamoto M, Vidmar JJ, Glass ADM. Regulation of Nrt1 and Nrt2 gene families of Arabidopsis thaliana: responses to nitrate provision. Plant Cell Physiol 2003;44:304-17.

Orsel M, Chopin F, Leleu O, Smith SJ, Krapp A, Daniel-Vedele F, et al. Characterization of a two-component high-affinity nitrate uptake system in Arabidopsis. Physiology and protein-protein interaction. Plant Physiol 2006;142:1304-17.

Orsel M, Krapp A, Daniel-Vedele F. Analysis of the NRT2 nitrate transporter family in Arabidopsis. Structure and gene expression. Plant Physiol 2002;129:886-96.

Rawat SR, Silim SN, Kronzucker HJ, Siddiqi MY, Glass ADM. AtAmt1 gene expression and $\mathrm{NH}_{4}{ }^{+}$uptake in roots of Arabidopsis thaliana: evidence for regulation by root glutamine levels. Plant J 1999;19:143-52.

Remans T, Nacry P, Pervent M, Girin T, Tillard P, Lepetit M, et al. A central role for the nitrate transporter NRT2.1 in the integrated morphological and physiological responses of the root system to nitrogen limitation in Arabidopsis. Plant Physiol 2006;140:909-21.

Rubin G, Tohge T, Matsuda F, Saito K, Scheible WR. Members of the LBD family of transcription factors repress anthocyanin synthesis and affect additional nitrogen responses in Arabidopsis. Plant Cell 2009;21:3567-84.

Wang R, Xing X, Wang Y, Tran A, Crawford NM. A genetic screen for nitrate regulatory mutants captures the nitrate transporter gene NRT1.1. Plant Physiol 2009;151:472-8.

Wirth J, Chopin F, Santoni V, Viennois G, Tillard P, Krapp A, et al. Regulation of root nitrate uptake at the NRT2.1 protein level in Arabidopsis thaliana. J Biol Chem 2007;282:23541-52.

Zhuo D, Okamoto M, Vidmar JJ, Glass ADM. Regulation of a putative highaffinity nitrate transporter (AtNrt2.1) in roots of Arabidopsis thaliana. Plant J 1999;17:563-8. 